\title{
ZAKRES I ZNACZENIE WYKONYWANIA PRZEZ NARODOWY BANK POLSKI NADZORU SYSTEMOWEGO NAD SYSTEMAMI PŁATNICZYMI
}

\section{Wstęp}

Do podstawowych regulacji dotyczących nadzoru systemowego nad systemami płatniczymi zalicza się przepisy prawa krajowego oraz regulacje unijne. Podstawa prawna wykonywania przez Narodowy Bank Polski (dalej: NBP) nadzoru systemowego nie została wskazana w jednym akcie prawnym, ani też nie została wyrażona wprost. W pierwszej kolejności należy odwołać się do ustawy z dnia 29 sierpnia 1997 r. o Narodowym Banku Polskim ${ }^{1}$, bowiem realizacja funkcji nadzorcy systemowego wiąże się w znacznej mierze z obowiązkiem wykonywania przez NBP zadań polegających w szczególności na organizowaniu rozliczeń pieniężnych i podejmowaniu działań na rzecz stabilności krajowego systemu finansowego. Ponadto, w myśl art. 3 ust 2 pkt 8 ustawy o Narodowym Banku Polskim, do zadań NBP należy wykonywanie innych zadań określonych ustawami. Kolejnym aktem prawnym odnoszącym się do nadzoru systemowego, jako funkcji NBP, jest ustawa z dnia 24 sierpnia 2001 r. o ostateczności rozrachunku w systemach płatności i systemach rozrachunku papierów wartościowych oraz zasadach nadzoru nad tymi systemami ${ }^{2}$. Stosowana jest ona $\mathrm{w}$ odniesieniu do systemów płatności i określa wyłączny nadzór Prezesa NBP poprzez wydawanie decyzji. Podstawy sprawowania nadzoru systemowego wynikają także z ustawy z dnia 19 sierpnia 2011 r.

\footnotetext{
* Dr, Uniwersytet Szczeciński; e-mail: ewa.kowalewska@usz.edu.pl, https://orcid.org/ 0000-0001-8167-6579.

1 Tekst jednolity: Dz. U. z 2020 r. poz. 2027.

2 Tekst jednolity: Dz. U. z 2019 r. poz. 212.
} 
o usługach płatniczych ${ }^{3}$, w odniesieniu do schematów płatniczych (określono wyłączny nadzór Prezesa NBP) oraz usługi acquiringu (w tym przypadku nadzór polega na współpracy Prezesa NBP z Komisją Nadzoru Finansowego - dalej: $\mathrm{KNF}^{4}$ ). Do aktów prawa krajowego, stanowiących podstawę prawną sprawowania nadzoru systemowego, należy także zaliczyć ustawę z dnia 29 lipca 2005 r. o obrocie instrumentami finansowy$\mathrm{mi}^{5}, \mathrm{w}$ odniesieniu do systemów rozliczeń i systemów rozrachunku papierów wartościowych (nadzór ten opiera się na współpracy Prezesa NBP $\mathrm{z} \mathrm{KNF}{ }^{6}$.

Wyżej wymienione przepisy zostały uzupełnione aktami wykonawczymi, m.in. rozporządzeniem Ministra Finansów z dnia 28 czerwca 2019 r. w sprawie funkcjonowania systemu płatności ${ }^{7}$, rozporządzeniem Ministra Rozwoju i Finansów z dnia 10 maja 2017 r. w sprawie funkcjonowania schematu płatniczego ${ }^{8}$. Natomiast wśród aktów prawa unijnego regulujących kwestie nadzoru systemowego znajdują się przede wszystkim: rozporządzenia CSDR ${ }^{9}$, rozporządzenie $\mathrm{EMIR}^{10}$ i rozporządzenie w sprawie opłat interchange ${ }^{11}$.

Standardy europejskie to głównie dokumenty opracowane przez działający przy Banku Rozrachunków Międzynarodowych Komitet ds.

\footnotetext{
3 Tekst jednolity: Dz. U. z 2020 r. poz. 794 z późn. zm.

4 Prezes NBP wydaje opinię w formie postanowienia, ale na wniosek KNF.

5 Tekst jednolity: Dz. U. z 2019 r. poz. 730 z późn. zm.

6 Patrz przyp. 4.

7 Dz. U. z 2019 r. poz. 1376. Obecnie obowiązuje rozporządzenie Ministra Finan-
} sów z dnia 28 czerwca 2019 r. w sprawie funkcjonowania systemu płatności.

8 Dz. U. z 2017 r. poz. 995.

9 Rozporządzenie Parlamentu Europejskiego i Rady (UE) 909/2014 z dnia 23 lipca 2014 r. w sprawie usprawnienia rozrachunku papierów wartościowych w Unii Europejskiej i w sprawie centralnych depozytów papierów wartościowych, zmieniające dyrektywy 98/26/WE i 2014/65/UE oraz rozporządzenie (UE) nr 236/2012, Dz. Urz. UE L 257/1 z 28.08.2014.

10 Rozporządzenie Parlamentu Europejskiego i Rady (UE) 648/2012 z dnia 4 lipca 2012 r. w sprawie instrumentów pochodnych będących przedmiotem obrotu poza rynkiem regulowanym, kontrahentów centralnych i repozytoriów transakcji, Dz. Urz. UE L 201/1 z 27.07.2017.

11 Rozporządzenie Parlamentu Europejskiego i Rady (UE) 2015/751 z dnia 29 kwietnia 2015 r. w sprawie opłat interchange w odniesieniu do transakcji płatniczych realizowanych w oparciu o kartę, Dz. Urz. UE L 123/1 z 19.05.2015 - zwane dalej rozporządzeniem 2015/751. 
Systemów Płatności i Rozrachunków ${ }^{12}$ oraz Komitet Techniczny Międzynarodowej Organizacji Komisji Papierów Wartościowych ${ }^{13}$. Należy podkreślić, że nadzór ten jest regulowany przez różnego rodzaju wytyczne uzupełniające, w szczególności ww. standardy międzynarodowe oraz wymagania Unii Europejskiej, przede wszystkim opracowane przez Europejski Bank Centralny. Wszystkie wymienione regulacje zawarto w dokumencie Polityka sprawowania nadzoru przez Narodowy Bank Polski w zakresie systemu płatniczego, który został przyjęty przez Zarząd NBP.

Wykonywanie nadzoru systemowego nad systemami płatniczymi przez NBP polega na podejmowaniu działań, które zmierzają do zapewnienia, by funkcjonowanie poszczególnych systemów, schematów oraz usługi acquiringu było sprawne, bezpieczne i zgodne z przepisami. Celem nadzoru jest przede wszystkim ograniczenie ryzyka systemowego poprzez zapewnienie sprawnego i bezpiecznego funkcjonowania systemu płatniczego oraz zgodności zasad funkcjonowania nadzorowanych systemów, schematów i usług z przepisami prawa ${ }^{14}$.

W pierwszej kolejności należy zwrócić uwagę na kwestie zachowania bezpieczeństwa systemu płatniczego, zwłaszcza dlatego, że są one warunkiem utrzymania stabilności całego systemu finansowego. $Z$ tego względu często porównuje się system płatniczy do krwiobiegu gospodarki. Znaczenie systemu płatniczego wzrasta również z powodu dynamicznego wzrostu liczby i wartości transakcji finansowych, które przekładają się na poziom obrotów w systemach płatności ${ }^{15}$. Za utrzymanie stabilności finansowej odpowiadają: bank centralny (NBP), instytucje nadzoru finansowego (KNF), system gwarantowania depozytów (Bankowy Fundusz Gwarancyjny) oraz rząd ${ }^{16}$. Zakłócenia w funkcjonowaniu systemu płatniczego mogą spowodować problemy związane z płynnością

12 Committee on Payment and Settlement System - CPSS, który od czerwca 2014 r. nosi nazwę Committee on Payments and Market Infrastructures - CPMI.

13 Technical Committee of the International Organization of Securities Commissions - IOSCO.

14 Polityka sprawowania przez Narodowy Bank Polski nadzoru systemowego w zakresie systemu płatniczego, czerwiec 2019 r.; materiał źródłowy ze strony internetowej: www.nbp.pl [dostęp: 12.09.2019 r.].

15 O. Szczepańska, Rola banku centralnego w sieci bezpieczeństwa finansowego, Bezpieczny Bank 2007, nr 2-3, s. 65.

16 P. Sotomska-Krzysztofik, O. Szczepańska, Przejrzystość banków centralnych we wspieraniu stabilności finansowej, Bank i Kredyt 2006, nr 11-12, s. 13 i n. 
u poszczególnych uczestników rozliczeń, a w dalszej kolejności wywołać zaburzenia w systemie finansowym nie tylko jednego państwa ${ }^{17}$.

Celem niniejszego opracowania jest przede wszystkim zbadanie efektywności obowiązującego systemu nadzoru, wykonywanego przez NBP, a także usystematyzowanie przyjętych w tytułowym zakresie rozwiązań prawnych. Hipotezę stanowi natomiast założenie, że prawidłowy i bezpieczny system płatniczy stanowi podstawę funkcjonowania określonych ustawowo systemów, schematów i usługi acquiringu. Ponadto weryfikacji poddano hipotezę o rozbudowanym zakresie nadzoru i jego ustawowym rozproszeniu. Podstawową metodą badawczą wykorzystaną w studium jest metoda dogmatyczno-prawna. Analizą objęto głównie obowiązujące ustawodawstwo i literaturę przedmiotu. W podsumowaniu natomiast przeanalizowano Raport o nadzorze systemowym w zakresie polskiego systemu płatniczego za $2017 \mathrm{r}$.

\section{Zakres nadzoru systemowego}

Nadzór systemowy obejmuje następujące elementy infrastruktury rynku finansowego, które mają wpływ na funkcjonowanie przepływu pieniądza w gospodarce:

- systemy płatności, tj: wysokokwotowe SORBNET 2 i TARGET 2, prowadzone przez NBP, oraz detaliczne: Elixir, Euro Elixir, Expres Eliksir i Inkart prowadzone przez Krajową Izbę Rozliczeniową SA (KIR SA), system płatności BlueCash prowadzony przez Blue Media SA, system płatności BLIK prowadzony przez Polski Standard Płatności Sp. z o.o. oraz Krajowy System Rozliczeń prowadzony przez First Data Polska SA;

- schematy płatnicze - będące systemami kart płatniczych (Visa Europe, Mastercard, American Express oraz Diners Club) oraz niebędące systemami kart płatniczych (schemat płatniczy BLIK, YetiPay, mPay, SkyCash, Smoopay, PeoPay);

- usługę acquringu świadczoną przez krajowe instytucje płatnicze (KIP);

17 J. Górka, Ryzyko w systemie płatniczym, Problemy Zarządzania 2013, t. 11, nr 2, s. 112-113. 
- systemy rozliczeń i systemy rozrachunku papierów wartościowych: SKARBNET4 System rejestracji bonów pieniężnych NBP i bonów skarbowych, których operatorem jest NBP, system rozrachunku transakcji zawieranych $\mathrm{w}$ obrocie instrumentami finansowymi prowadzony przez Krajowy Depozyt Papierów Wartościowych SA, systemy rozliczeń prowadzone przez KDPW_CCP SA dla transakcji, których przedmiotem są instrumenty finansowe, system rozliczeń i rozrachunku instrumentów finansowych IRGiT SRF ${ }^{18}$ prowadzony przez Izbę Rozliczeniową Giełd Towarowych SA.

Zgodnie $\mathrm{z}$ definicją zawartą $\mathrm{w}$ ustawie o ostateczności rozrachunku "system płatności" oznacza podlegające prawu polskiemu, prawne powiązania pomiędzy co najmniej trzema instytucjami, w tym co najmniej jedną z następujących: NBP, bank centralny innego państwa, bank krajowy, oddział banku zagranicznego, instytucja kredytowa oraz oddział instytucji kredytowej ${ }^{19}$, spółdzielcza kasa oszczędnościowo-kredytowa oraz Krajowa Spółdzielcza Kasa Oszczędnościowo-Kredytowa ${ }^{20}$, firma inwestycyjna lub organ władzy publicznej. Obowiązują wspólne dla tych uczestników zasady przeprowadzania rozliczeń lub realizacji ich zleceń rozrachunku, z wyłączeniem uczestnika pośredniego (zlecenie uczestnika dotyczące przekazania kwoty pieniężnej na rachunek odbiorcy prowadzony przez agenta rozrachunkowego lub inne zlecenie, które powoduje wykonanie lub zwolnienie ze zobowiązania pieniężnego, zgodnie z zasadami systemu płatności, lub zlecenie uczestnika dotyczące przeniesienia papierów wartościowych w drodze dokonania odpowiednich zapisów $\mathrm{w}$ prowadzonej ewidencji papierów wartościowych lub w inny sposób). Ustawodawca wskazuje trzy instytucje, w ramach których obowiązują wspólne dla uczestników tego systemu zasady przeprowadzania rozliczeń lub realizacji ich zleceń rozrachunku.

System płatności służy do dokonywania rozliczeń lub rozrachunku zleceń płatniczych przekazywanych do systemu przez uczestników związanych umową z operatorem systemu. Zlecenie rozrachunku to zlecenie uczestnika systemu płatności dotyczące przekazania kwoty pieniężnej na

18 SRF - system rozliczeń na rynku towarowym.

19 W rozumieniu ustawy z dnia 29 sierpnia 1997 r. - Prawo bankowe, tekst jednolity: Dz. U. z 2020 r. poz. 1896 z późn. zm.

20 W rozumieniu ustawy z dnia 5 listopada 2009 r. o spółdzielczych kasach oszczędnościowo-kredytowych, tekst jednolity: Dz. U. z 2020 r. poz. 1643 z późn. zm. 
rachunek odbiorcy lub inne zlecenia, które powodują wykonanie zobowiązania pieniężnego bądź zwolnienie z niego, zgodnie z zasadami systemu płatności. Rozliczenie prowadzi do obliczenia wartości netto zobowiązań uczestników systemu zgodnie z instrukcjami przekazanymi do systemu w danym okresie, zawierającym zbiory zleceń płatniczych od uczestników. Rozrachunek polega na transferze odpowiedniej ilości środków pieniężnych między rachunkami uczestników poprzez odpowiednie obciążenie i uznanie rachunków uczestników kwotą wynikającą z dokonanego rozliczenia ${ }^{21}$.

Termin „system płatności” został zdefiniowany również w ustawie o usługach płatniczych, gdzie w myśl art. 2 pkt 27 przez system płatności rozumie się system transferu środków pieniężnych oparty na formalnych i znormalizowanych regułach oraz wspólnych zasadach dotyczących przetwarzania, rozliczeń lub rozrachunku transakcji płatniczych. System płatności pozwala na dokonywanie rozliczeń transakcji różnymi instrumentami płatniczymi, tj. gotówką, kartą płatniczą, poleceniem przelewu, poleceniem zapłaty czy pieniądzem elektronicznym. Podmiot, który prowadzi dany system płatności, zawiera umowę z dostawcą usług płatniczych ${ }^{22}$.

Definicja pojęcia "schemat płatniczy" została wprowadzona do ustawodawstwa za sprawą nowelizacji ustawy o usługach płatniczych w 2016 r. ${ }^{23}$ poprzez dodanie do art. 2 pkt 26a. Schemat płatniczy to zbiór zasad przeprowadzania transakcji płatniczych, wydawania i akceptowania przez dostawców usług płatniczych instrumentów płatniczych i przetwarzania transakcji płatniczych, wykonywanych przy użyciu instrumentów płatniczych oraz system kart płatniczych ${ }^{24}$. Schemat płatniczy służy do zarządzania funkcjonowaniem instrumentu płatniczego $\mathrm{w}$ obrocie, czyli przeprowadzania transakcji przy jego użyciu. W związku z tym w ramach schematu płatniczego następuje określenie:

${ }^{21}$ Polityka sprawowania przez Narodowy Bank Polski nadzoru systemowego w zakresie systemu płatniczego, czerwiec 2017 r.; materiał źródłowy ze strony internetowej: www.nbp.pl [dostęp: 12.09.2018 r.].

22 B. Bajor, w: Ustawa o ustugach płatniczych. Komentarz, red. A. Zalcewicz, Warszawa 2016, s. 81.

23 Ustawa z dnia 30 listopada 2016 r. o zmianie ustawy o usługach płatniczych oraz niektórych innych ustaw, Dz. U. z 2016 r. poz. 1997.

24 Mowa tu o systemie kart płatniczych w rozumieniu art. 2 pkt 16 rozporządzenia $2015 / 751$. 
- warunków jego wydawania przez wydawców;

- zasad akceptowania transakcji płatniczych przez agentów rozliczeniowych na rzecz akceptantów;

- zasad przetwarzania transakcji płatniczych, które polegają głównie na weryfikacji instrumentu, użytkownika, dostępności środków, a następnie na podjęciu działań w celu transferu środków pieniężnych.

Należy zauważyć, że zgodnie z obowiązującą definicją wyróżnia się dwa rodzaje schematów płatniczych: kartowe oraz niekartowe (np. schematem niekartowym jest schemat mPay czy też schemat M-PESA). Schemat płatniczy to tylko pewien zbiór zasad, który należy odróżnić od zasad funkcjonowania schematu płatniczego (wymienionych w katalogu $\mathrm{z}$ art. 132zp ustawy o usługach płatniczych).

W prawie UE schemat płatniczy (nazywany schematem płatności) został zdefiniowany w art. 2 pkt 7 rozporządzenia Parlamentu Europejskiego i Rady (UE) 260/2012 z dnia 14 marca 2012 r. ustanawiającego wymogi techniczne $\mathrm{i}$ handlowe $\mathrm{w}$ odniesieniu do poleceń przelewu i poleceń zapłaty w euro oraz zmieniające rozporządzenie (WE) 924/200925. Według tej regulacji "schemat płatności” oznacza jednolity zbiór zasad, praktyk, standardów lub wytycznych wdrożeniowych uzgodnionych przez dostawców usług płatniczych w odniesieniu do wykonywania płatności w całej UE i w państwach członkowskich, który jest odrębny od wszelkiej infrastruktury lub wszelkich systemów płatności, które umożliwiają jego stosowanie.

Schematem płatniczym zarządza organizacja płatnicza, która może jednocześnie pełnić funkcję wydawcy lub agenta rozliczeniowego. Organizacja ta uczestniczy w przetwarzaniu transakcji płatniczych, sprowadzających się do przesyłania informacji od agenta rozliczeniowego do wydawcy w celu zweryfikowania czynników niezbędnych do przeprowadzenia transakcji.

Szczególne zasady funkcjonowania schematu płatniczego odnoszą się do czterostronnego schematu płatniczego. Występuje on wówczas, gdy organizacja płatnicza nie wykonuje żadnych czynności wydawcy albo agenta rozliczeniowego, a powierza te działania innym dostawcom usług płatniczych. Organizacją płatniczą jest również organizacja kartowa, czyli podmiot, w tym określony organ lub organizacja, oraz podmiot,

25 Dz. Urz. UE L 94/ 22 z 30.03.2012. 
o którym mowa w art. 2 pkt 16 rozporządzenia 2015/751, określający zasady funkcjonowania systemu kart płatniczych oraz odpowiedzialny za podejmowanie decyzji dotyczących funkcjonowania systemu kart płatniczych (nowy pkt 19b w art. 2 ustawy o usługach płatniczych). Prowadzenie takiego schematu płatniczego wymaga uzyskania zezwolenia Prezesa NBP. W ramach czterostronnego schematu płatniczego należy wyróżnić następujące ogniwa: płatnik (użytkownik instrumentu), akceptant (sklep), wydawca, agent rozliczeniowy oraz organizacja płatnicza.

Usługi acquiringu polegają na akceptowaniu i przetwarzaniu transakcji płatniczych wykonywanych przy użyciu instrumentu płatniczego płatnika, w celu dokonania transferu środków pieniężnych do odbiorcy. W myśl postanowień Dyrektywy Parlamentu Europejskiego i Rady (UE) 2015/2366 z dnia 25 listopada 2015 r. w sprawie usług płatniczych w ramach rynku wewnętrznego ${ }^{26}$ acquiring oznacza usługę płatniczą świadczoną przez dostawcę usług płatniczych, który zawiera z odbiorcą umowę o akceptowaniu i przetwarzaniu transakcji płatniczych, czego skutkiem jest transfer środków pieniężnych do odbiorcy. Termin usługa acquiringu został zdefiniowany także w ustawie o usługach płatniczych. Usługa ta polega na umożliwieniu wykonania transakcji płatniczych zainicjowanych przez akceptanta lub za jego pośrednictwem instrumentem płatniczym płatnika, w szczególności na obsłudze autoryzacji, przesyłaniu do wydawcy karty płatniczej lub systemów płatności zleceń płatniczych płatnika lub akceptanta, mających na celu przekazanie akceptantowi należnych mu środków, z wyłączeniem czynności polegających na jej rozliczaniu i rozrachunku stosownie do postanowień ustawy o ostateczności rozrachunku ${ }^{27}$. Usługa acquiringu polega na obsłudze autoryzacji oraz przesłaniu zleceń płatniczych do wydawcy karty płatniczej lub systemów płatności. W usłudze tej istotną rolę spełnia agent rozliczeniowy, a jest świadczona na rzecz akceptanta, czyli podmiotu będącego odbiorcą środków pieniężnych. Jej podstawą jest umowa zawarta między ww. podmiotami.

Zakres nadzoru systemowego obejmuje także system rozliczeń i rozrachunku papierów wartościowych. Służy on do rozliczania oraz

26 Dz. Urz. UE L 337/35 z 23.12.2015.

27 Polityka sprawowania przez Narodowy Bank Polski nadzoru systemowego w zakresie systemu płatniczego, czerwiec 2018 r.; materiał źródłowy ze strony internetowej: www.nbp.pl [dostęp: 12.09.2019 r.]. 
rozrachunku transakcji zawieranych w obrocie instrumentami finansowymi. Rozliczenie transakcji $\mathrm{w}$ obrocie instrumentami finansowymi to zespół czynności dokonywanych po zawarciu transakcji, w ramach którego ustala się wysokość zobowiązań stron transakcji oraz sprawdza dostępność instrumentów finansowych i środków pieniężnych potrzebnych do wypełniania tych zobowiązań2 ${ }^{28}$. Rozliczenie transakcji zawieranych $\mathrm{np}$. na giełdzie dokonywane jest w systemie rozliczeń papierów wartościowych. Taki system rozliczeń prowadzi izba rozliczeniowa. W tym trybie dokonuje się ustalenia wysokości zobowiązań z poszczególnych transakcji. Izba rozliczeniowa informuje następnie strony transakcji o ich należnościach i zobowiązaniach. Ostatnim etapem rozliczenia jest sprawdzenie dostępności instrumentów finansowych i środków pieniężnych potrzebnych do realizacji zobowiązań. Na zakończenie transakcja kierowana jest do rozrachunku, czyli końcowego etapu procesu wykonywania transakcji. Jego istota polega przede wszystkim na przeniesieniu praw $\mathrm{z}$ instrumentów finansowych poprzez obciążenie rachunku strony sprzedającej instrumenty finansowe, czyli zbywcy, oraz uznaniu rachunku strony kupującej te instrumenty, tj. nabywcy. Ponadto następuje dokonanie przepływu pieniężnego z rachunku nabywcy na rachunek zbywcy. Należy podkreślić, że celem rozrachunku jest wykonanie, czyli zamknięcie transakcji. De facto dochodzi do rozrachunku w zakresie instrumentów finansowych oraz rozrachunku pieniężnego.

\section{Uprawnienia nadzorcze Prezesa NBP}

Powszechnie przyjmuje się, głównie w praktyce NBP, że podstawa wykonywania przez Prezesa NBP nadzoru systemowego została zawarta w rozdziale 3 ustawy o ostateczności rozrachunku. Rozdział ten, zatytułowany Zasady nadzoru, odnosi się do kompetencji NBP w zakresie systemów płatności. Wykładnia językowa treści art. 16 ustawy o ostateczności rozrachunku prowadzi do fundamentalnego wniosku, że prowadzenie systemów płatności wymaga zezwolenia Prezesa NBP. Ponadto zezwolenia

28 Nadzór systemowy w zakresie systemu płatniczego, s. 10-11, dokument dostępny pod adresem: http://www.nbp.pl/systemplatniczy/nadzor/polityka.pdf [dostęp: 20.09.2019 r.]. 
wymaga wprowadzanie jakichkolwiek zmian w zasadach funkcjonowania systemu. Zważywszy na te kwestie, należy postawić pytanie o granice nadzoru.

Na gruncie nauki o administracji nadzór jest rozumiany jako pojęcie szersze od kontroli, obejmujące swym zakresem także stosowanie środków nadzorczych. O nadzorze mówi się wówczas, gdy występuje prawo wydawania poleceń i dyrektyw, które mają wiążący charakter. Nadzór nie ogranicza się jedynie do obserwacji czy porównywania stanu obecnego ze stanem pożądanym. Nadzór łączy się z możliwością stosowania środków nadzorczych ${ }^{29}$, czyli władczego oddziaływania. W doktrynie podkreśla się, że nadzór obejmuje elementy przypisane kontroli, połączone z możliwością ingerencji w działalność podmiotu nadzorowanego ${ }^{30}$.

Mając na uwadze dorobek literatury przedmiotu, należałoby się również zastanowić, czy Prezes NBP z uprawnieniami, jakie mu przysługują w ramach systemów płatności, faktycznie wykonuje nadzór? Czy może jednak przypisanie NBP funkcji nadzorcy systemowego wynika z praktyki, jaka występuje w innych państwach UE, i jest naturalną konsekwencją współodpowiedzialności banku centralnego za stabilność systemu finansowego? Można odnieść wrażenie, że zamiar ustawodawcy, odnoszący się do nadania cech właściwych nadzorowi i znanych w przede wszystkim z prawa administracyjnego, nie został zrealizowany w sposób kompleksowy i właściwy.

Trzeba podkreślić, że wymóg uzyskiwania zezwolenia Prezesa NBP na prowadzenie systemów płatności poprzedzony był wymogiem uzyskiwania zgody. Zmiana treści art. 16 ustawy o ostateczności rozrachunku została wprowadzona na mocy art. 69 ustawy z dnia 6 marca 2018 r. Przepisy wprowadzające ustawę - Prawo przedsiębiorców oraz inne ustawy dotyczące działalności gospodarczej ${ }^{31}$. W takim brzmieniu art. 16 ustawy o ostateczności rozrachunku obowiązuje od dnia 30 kwietnia 2018 r. Zadanie Prezesa NBP zostało wzmocnione, gdyż zezwolenie wywołuje istotne skutki prawne, choćby w brzmieniu ustawy Prawo przedsiębiorców. Ponadto regulacja ta jest kompatybilna z uprawnieniem KNF, nadanym w tej samej ustawie, które polega na wydawaniu zezwolenia. W działalności NBP od dawna znana jest instytucja wydawania zezwoleń, tj.

\footnotetext{
29 E. Ochendowski, Prawo administracyjne. Część ogólna, Torun 2013, s. 377.

30 J. Jagielski, Kontrola administracji publicznej, Warszawa 2012, s. 12.

31 Tekst jednolity: Dz. U. z 2018 r. poz. 650.
} 
zezwoleń dewizowych, $\mathrm{w}$ rozumieniu i na zasadach określonych w ustawie z dnia 27 lipca 2002 r. - Prawo dewizowe ${ }^{32}$. Należy także zaznaczyć, że Prezes NBP wydaje zezwolenia dewizowe $\mathrm{w}$ formie decyzji administracyjnej. Można zatem sądzić, że zezwolenia udzielone w trybie art. 16 ustawy o ostateczności rozrachunku mają również postać decyzji administracyjnej.

Termin „zgoda” oznacza wyrażenie aprobaty, pozwolenie na coś. "Zezwolenie" natomiast można definiować jako pewne uprawnienie, jako przyznanie gwarancji np. prowadzenia określonego rodzaju działalności gospodarczej. Na gruncie obowiązującego ustawodawstwa, tj. art. 44 ustawy Prawo przedsiębiorców, tylko koncesja, zezwolenie albo wpis do rejestru działalności regulowanej uprawniają do wykonywania działalności gospodarczej. Na gruncie ww. ustawy ranga zezwolenia została wzmocniona. W ustawie o swobodzie działalności gospodarczej ${ }^{33}$ do wykonywania działalności gospodarczej uprawniały obok koncesji, zezwolenia i wpisu do rejestru działalności regulowanej także zgoda i licencja.

Należy podkreślić, że brak wyraźnej podstawy prawnej do wykonywania przez Prezesa NBP nadzoru, który z założenia wiąże się z możliwością władczego oddziaływania na podmiot objęty nadzorem, może budzić zastrzeżenia (przede wszystkim natury formalnej). Naprzeciw tym wątpliwościom ustawodawca wyszedł jedynie w znowelizowanej ustawie o usługach płatniczych, w nowym art. 132zl, który jednak odnosi się wyłącznie do nadzoru nad schematami płatniczymi.

W ramach nadzoru systemowego, o którym mowa w ustawie o ostateczności rozrachunku, Prezes NBP:

- wydaje zezwolenia na prowadzenie systemu płatności oraz wprowadzenie zmian w zasadach jego funkcjonowania;

- dokonuje kompleksowych ocen systemu płatności w trakcie jego funkcjonowania;

- wydaje zalecenia podmiotom prowadzącym system płatności.

Na potrzeby nadzoru systemowego podzielono systemy płatności na systemowo ważne systemy płatności, istotne systemy płatności detalicznych i pozostałe systemy płatności detalicznych. Listę tych systemów przedstawia poniższa tabela.

32 Tekst jednolity: Dz. U. z 2020 r. poz. 1708.

33 Ustawa z dnia 2 lipca 2004 r. o swobodzie działalności gospodarczej, tekst jednolity: Dz. U. z 2017 r. poz. 2168 z późn. zm. 
Tabela 1. Lista systemów płatności podlegających nadzorowi systemowemu Prezesa NBP

\begin{tabular}{|l|l|l|}
\hline \multicolumn{1}{|c|}{ System } & \multicolumn{1}{|c|}{ Operator } & \multicolumn{1}{c|}{ Informacje } \\
\hline SORBNET 2 & NBP & $\begin{array}{l}\text { system płatności } \\
\text { wysokokwotowych w złotych }\end{array}$ \\
\hline TARGET 2 & NBP & $\begin{array}{l}\text { system płatności wysokokwoto- } \\
\text { wych w euro, komponent } \\
\text { systemu płatności TARGET 2 }\end{array}$ \\
\hline Elixir & $\begin{array}{l}\text { Krajowa Izba } \\
\text { Rozliczeniowa S.A. }\end{array}$ & $\begin{array}{l}\text { system płatności } \\
\text { detalicznych w złotych }\end{array}$ \\
\hline Euro Elixir & $\begin{array}{l}\text { Krajowa Izba } \\
\text { Rozliczeniowa S.A. }\end{array}$ & $\begin{array}{l}\text { system płatności } \\
\text { detalicznych w euro }\end{array}$ \\
\hline Express Elixir & $\begin{array}{l}\text { Krajowa Izba } \\
\text { Rozliczeniowa S.A. }\end{array}$ & system płatności natychmiastowych \\
\hline System Płatności BlueCash & Blue Media S.A. & system płatności natychmiastowych \\
\hline Krajowy System Rozliczeń & First Data Polska S.A. & system płatności kartowych \\
\hline System Płatności BLIK & $\begin{array}{l}\text { Polski Standard } \\
\text { Płatności Sp. z o.o. }\end{array}$ & system płatności mobilnych \\
\hline
\end{tabular}

Źródło: http://www.nbp.pl/systemplatniczy/nadzor/lista-systemow-i-schematow.pdf [dostęp: 2.11.2019 r.].

Zakwalifikowanie systemu nowo tworzonego albo już istniejącego do jednej z ww. kategorii następuje na podstawie indywidualnej oceny NBP. Do kryteriów, które brane są pod uwagę przy takiej ocenie, zalicza się:

1. Zakres oddziaływania na rynek finansowy - rozmiary systemu i powiązane z tym ryzyko finansowe dla uczestników i systemu finansowego jako całości.

2. Poziom penetracji rynku.

3. Obszar oddziaływania.

4. Przeprowadzenie rozrachunków dla innej IRF - zakres wertykalnych powiązań międzyinstytucjonalnych. 
Ponadto do oceny systemów płatności NBP stosuje się standardy zawarte $\mathrm{w}$ dokumencie Zasady dotyczące infrastruktury rynków finansowych $^{34}$, które odnoszą się do kwalifikacji systemu.

Podmioty prowadzące systemy płatności przekazują do NBP dane sprawozdawcze na potrzeby prowadzenia analiz polskiego systemu płatniczego oraz na podstawie art. 18 ust. 6a ustawy o ostateczności rozrachunku podmioty te są zobowiązane do przekazania danych dotyczących bieżącego funkcjonowania systemów płatności, cyklicznie albo po wystąpieniu określonego zdarzenia, oraz informacji o incydentach. Należy podkreślić, że szczegółowy zakres takich obowiązków sprawozdawczych został określony $\mathrm{w}$ rozporządzeniu $\mathrm{w}$ sprawie funkcjonowania systemu płatności. NBP dokonuje weryfikacji powyższych sprawozdań na podstawie wytycznych w zakresie obowiązków sprawozdawczych podmiotów prowadzących systemy płatności.

Wykonywanie przez Prezesa NBP nadzoru w ramach funkcjonowania schematów płatniczych odbywa się na zasadach określonych w ustawie o usługach płatniczych, zaprowadzonych nowelizacją z 2016 r. Wprowadzenie nowych uprawnień nadzorczych dla Prezesa NBP miało stanowić dopełnienie kompetencji nadzorczych Prezesa NBP w zakresie sprawowanego nadzoru systemowego nad systemami płatności.

Zgodnie z treścią art. 132zl ustawy o usługach płatniczych Prezes NBP podejmuje $\mathrm{w}$ ramach nadzoru nad schematami płatności, czynności, które polegają w szczególności na:

1) wydawaniu zezwolenia na prowadzenie schematu płatniczego oraz zezwolenia na zmianę zasad funkcjonowania schematu płatniczego;

2) dokonywaniu oceny funkcjonowania schematów płatniczych;

3) żądaniu przedstawienia informacji lub dokumentów niezbędnych do oceny funkcjonowania schematu płatniczego;

4) pozyskiwaniu informacji o prowadzonej działalności;

5) wydawaniu zaleceń;

6) wydawaniu decyzji o czasowym, częściowym albo całkowitym wstrzymaniu funkcjonowania schematu płatniczego albo cofnięciu zezwolenia na prowadzenie schematu płatniczego;

7) nakładaniu kar pieniężnych.

34 Principles for financial market infrastructures (PFMIs), CPSS-IOSCO (obecnie CPMI-IOSCO), kwiecień 2012 r., materiał źródłowy ze strony internetowej: http:/ / www.bis.org/cpmi/publ/d101a.pdf [dostęp: 1.11.2019 r.]. 
Należy zaznaczyć, że prowadzenie schematu płatniczego oraz zmiana zasad funkcjonowania schematu płatniczego wymaga zezwolenia Prezesa NBP. Prezes NBP wydaje zezwolenie, jeżeli zasady dostępu do schematu płatniczego są ustalone według obiektywnych, równych i proporcjonalnych kryteriów, a ograniczenia w dostępie do tego schematu nie mogą być większe, niż jest to konieczne ze względu na ochronę przed określonymi rodzajami ryzyka, takimi jak ryzyko rozrachunkowe, ryzyko operacyjne i ryzyko biznesowe, oraz ze względu na ochronę finansową i operacyjną stabilności schematu płatniczego. Ustawodawca określił, że organizacja płatnicza składa wniosek o wydanie zgody co najmniej na 3 miesiące przed planowanym rozpoczęciem funkcjonowania schematu płatniczego lub co najmniej na 3 miesiące przed planowanym wprowadzeniem zmian w zasadach funkcjonowania tego schematu.

Prezes NBP odmawia wydania zezwolenia, jeżeli:

1) zasady funkcjonowania schematu płatniczego są niezgodne z przepisami prawa;

2) nie zostały zapewnione bezpieczeństwo lub sprawność funkcjonowania schematu płatniczego albo systemu płatności, w którym są dokonywane przetwarzanie, rozliczenie lub rozrachunek płatności $\mathrm{w}$ ramach schematu płatniczego;

3) zasady funkcjonowania schematu płatniczego nie spełniają wymogów określonych $w$ art. 132zm ust. 3 lub art. 132zp ust. 4 ustawy o usługach płatniczych.

Ustawodawca uregulował także sytuacje, w których zezwolenie Prezesa NBP nie jest wymagane, tj. jeżeli organizacja płatnicza jest jednocześnie jedynym wydawcą instrumentu płatniczego oraz jedynym podmiotem świadczącym usługę, a także gdy organizacja płatnicza podlega nadzorowi odpowiedniego organu nadzoru państwa członkowskiego innego niż Rzeczpospolita Polska lub odpowiedniego organu UE.

Ponadto Prezes NBP ma uprawnienia do zbierania informacji oraz danych statystycznych od organizacji płatniczych związanych z prowadzeniem schematu płatniczego. Lista schematów płatniczych podlegających nadzorowi systemowemu Prezesa NBP została zaprezentowana w poniższej tabeli. 
Tabela 2. Lista schematów płatniczych podlegających nadzorowi systemowemu Prezesa NBP

\begin{tabular}{|l|l|l|}
\hline \multicolumn{1}{|c|}{$\begin{array}{c}\text { Nazwa } \\
\text { schematu płatniczego }\end{array}$} & \multicolumn{1}{c|}{$\begin{array}{c}\text { Nazwa } \\
\text { organizacji płatniczej }\end{array}$} & \multicolumn{1}{c|}{$\begin{array}{c}\text { Rodzaj instrumentu } \\
\text { płatniczego }\end{array}$} \\
\hline Visa Europe & Visa Europe Limited & karta płatnicza \\
\hline Mastercard & MasterCard Europe S.A. & karta płatnicza \\
\hline American Express & $\begin{array}{l}\text { American Express Services } \\
\text { Europe Limited }\end{array}$ & karta płatnicza \\
\hline Diners Club & Diners Club & karta płatnicza \\
\hline $\begin{array}{l}\text { Polski Standard } \\
\text { Płatności Sp. z o.o. }\end{array}$ & Schemat płatniczy BLIK & aplikacja mobilna \\
\hline YetiPay Sp. z o.o. & YetiPay & portfel elektroniczny \\
\hline mPay S.A. & mPay & aplikacja mobilna \\
\hline SkyCash Poland S.A. & SkyCash & portfel elektroniczny \\
\hline Planet Pay Sp. z o.o. & Smoopay & aplikacja mobilna \\
\hline
\end{tabular}

Źródło: opracowanie własne na podstawie www.nbp.pl [dostęp: 2.11.2019 r.].

Należy odnotować, że system rozliczeń i rozrachunku papierów wartościowych jest $w$ ramach obowiązującego porządku prawnego nadzorowany przez KNF, z wyłączeniem systemów prowadzonych przez NBP. W takiej sytuacji rola Prezesa NBP sprowadza się do systemowej oceny funkcjonowania ww. systemów i podmiotów pod kątem sprawności, bezpieczeństwa oraz zgodności z prawem ${ }^{35}$.

W ramach systemu rozliczeń i rozrachunku papierów wartościowych Prezes NBP wykorzystuje następujące instrumenty nadzorcze:

- wydaje, na wniosek KNF, opinie dotyczące m.in. udzielania zezwoleń na prowadzenie izb rozliczeniowych i izb rozrachunkowych, a także zatwierdzania regulaminów KDPW, spółki której KDPW SA przekazał wykonywanie niektórych czynności izby rozliczeniowych i izb rozrachunkowych;

- współpracuje z KNF w zakresie udzielania zezwoleń CCP oraz centralnym depozytom papierów wartościowych, a także $\mathrm{w}$ zakresie bieżącego nadzoru nad tymi podmiotami;

35 Nadzór systemowy w zakresie systemu płatniczego, s. 12. 
- zbiera dane statystyczne oraz informacje dotyczące rozliczeń i rozrachunków dokonywanych w poszczególnych systemach, jak również informacje dotyczące incydentów występujących w tych systemach;

- stosuje instrumenty oparte na autorytecie banku centralnego.

Nad krajowymi instytucjami płatniczymi oraz świadczącymi usługę acquiringu nadzór wykonuje KNF. Udział Prezesa NBP polega na opiniowaniu wniosków o wydawanie zezwoleń na świadczenie usług płatniczych obejmujących usługę acquiringu. Ponadto Prezes NBP dokonuje oceny sposobu świadczenia usług acquiringu według kryterium sprawności, bezpieczeństwa oraz zgodności z przepisami prawa. Prezes NBP ma także uprawnienia do zbierania danych statystycznych dotyczących działalności agentów rozliczeniowych ${ }^{36}$.

Prezes NBP w ramach wykonywanego nadzoru systemowego nad schematami płatniczymi może wydać decyzję o czasowym, częściowym albo całkowitym wstrzymaniu funkcjonowania schematu płatniczego, albo cofnięciu zezwolenia na prowadzenie schematu płatniczego. Taką decyzję może wydać, gdy działanie schematu płatniczego będzie sprzeczne z prawem, gdy będzie stwarzać zagrożenie dla użytkowników, stabilności systemu płatniczego, bezpieczeństwa lub sprawności funkcjonowania systemów płatności, a także w przypadku zmiany zasad funkcjonowania schematu bez uzyskania zezwolenia Prezesa NBP. Może to oznaczać wstrzymanie realizacji transakcji w schemacie. Trzeba również odnotować, że prowadzenie schematu płatniczego bez wymaganej zgody Prezesa NBP jest zagrożone karą pieniężną.

\section{Wnioski wynikające $\mathrm{z}$ raportu o nadzorze systemowym w zakresie polskiego systemu płatniczego za $2018 r^{37}$}

Na gruncie obowiązującego ustawodawstwa wyróżnić należy nadzór systemowy (oversight) oraz nadzór ostrożnościowy (supervision). Pierwszy wykonywany jest przez Prezesa NBP, drugi natomiast należy do

36 Tamże, s. 14.

37 Raport o nadzorze systemowym w zakresie polskiego systemu płatniczego za 2017 r., grudzień 2018 r.; https://www.nbp.pl/systemplatniczy/nadzor/Raport-o-nadzorzesytemowym-2017.pdf [dostęp: 20.09.2018 r.]. 
kompetencji KNF. Podejmowanie przez NBP działań w ramach nadzoru systemowego wiąże się ściśle z odpowiedzialnością NBP za organizację rozliczeń pieniężnych oraz współodpowiedzialnością za utrzymanie stabilności sektora finansowego.

Sprawowanie nadzoru systemowego w 2018 r. odbywało się na podstawie Polityki sprawowania przez NBP nadzoru systemowego w zakresie systemu płatniczego, zatwierdzonej przez Zarząd NBP w październiku 2015 r. ${ }^{38}$ oraz jej aktualizacji zatwierdzonej przez Zarząd NBP w czerwcu 2017 r. i polegało na:

1. Pozyskiwaniu informacji o bieżącej działalności od nadzorowanych podmiotów.

2. Ocenie tej działalności.

3. Podejmowaniu działań na rzecz wprowadzenia niezbędnych zmian w sposobie funkcjonowania wszystkich systemów i świadczenia usługi acquiringu.

Zauważyć należy, że w 2017 r. NBP otrzymał uprawnienia do zbierania danych o charakterze nadzorczym od podmiotów działających w ramach infrastruktury systemu płatniczego. Zmiany te wynikały z potrzeby dostosowania polskiego ustawodawstwa m.in. do rozporządzenia Parlamentu Europejskiego i Rady (UE) 2015/751 z dnia 29 kwietnia 2015 r. $\mathrm{w}$ sprawie opłat interchange $\mathrm{w}$ odniesieniu do transakcji płatniczych realizowanych w oparciu o kartę oraz dyrektywy Parlamentu Europejskiego i Rady 2014/92/UE z dnia 23 lipca 2014 r. w sprawie porównywalności opłat związanych z rachunkami płatniczymi, przenoszenia rachunku płatniczego oraz dostępu do podstawowego rachunku płatniczego. $W$ wyniku tej zmiany powierzono Prezesowi NBP nadzór nad funkcjonowaniem wszystkich schematów płatniczych, co oznacza szerszy zakres niż ten wynikający z wcześniejszych przepisów ${ }^{39}$. Ponadto w 2017 r. przepisy dotyczące ww. nadzoru zostały doprecyzowane w aktach wykonawczych: w rozporządzeniu z dnia 8 maja 2017 r. w sprawie danych i informacji przekazywanych przez podmioty prowadzące depozyt papierów wartościowych, system rejestracji instrumentów finansowych niebędących papierami wartościowymi oraz systemem rozrachunku ${ }^{40}$, rozporządzeniu

38 http://www.nbp.pl/systemplatniczy/nadzor/polityka.pdf [dostęp: 2.11.2019 r.].

39 Por. raport o nadzorze systemowym w zakresie polskiego systemu płatniczego za 2017 r., grudzień 2018 r., s. 7.

40 Dz. U. z 2017 r. poz. 948. 
z dnia 10 maja 2017 r. w sprawie funkcjonowania schematu płatniczego ${ }^{41}$ oraz w rozporządzeniu z dnia 17 maja 2017 r. w sprawie funkcjonowania systemu płatności ${ }^{42}$.

Do najważniejszych narzędzi, dzięki którym Prezes NBP może prawidłowo wypełniać funkcję nadzorcy systemowego, zaliczyć trzeba: analizę danych ilościowych, wyjaśnianie incydentów występujących w systemach oraz schematach płatniczych oraz bieżącą współpracę z podmiotami prowadzącymi systemy, schematy płatnicze i świadczącymi usługę acquiringu.

Infrastruktura systemu płatniczego nadzorowanego przez Prezesa NBP w 2018 r. obejmowała:

- bezpośrednio: systemy płatności i schematy płatnicze;

- pośrednio: systemy rozrachunku papierów wartościowych, systemy rozliczeń papierów wartościowych, usługę acquiringu.

Nadzór systemowy w 2018 r. polegał głównie na:

- rozpatrywaniu wniosków składanych przez podmioty, dotyczących rozpoczęcia prowadzenia systemu płatności lub schematu płatniczego bądź wprowadzenia zmian w ich zasadach funkcjonowania;

- opiniowaniu wniosków dla KNF, dotyczących nadzoru nad systemami rozliczeń i systemami rozrachunku papierów wartościowych oraz świadczeniem dla KIP usługi acquiringu;

- pozyskiwaniu informacji o bieżącej działalności nadzorowanej infrastruktury systemu płatniczego, dokonywaniu oceny tej działalności;

- podejmowaniu działań na rzecz wprowadzenia niezbędnych zmian w sposobie jej funkcjonowania ${ }^{43}$.

W 2018 r. NBP podejmował głównie działania związane z monitorowaniem funkcjonowania infrastruktury systemu płatniczego z wykorzystaniem informacji pochodzących odpowiednio od operatorów systemów bądź podmiotów prowadzących schematy płatnicze. Działania te miały na celu kontrolę zapewnienia bezpiecznego i zgodnego z prawem funkcjonowania systemów i schematów. Prezes NBP wydał w 2018 r., na podstawie art. 16 ust. 1 i 3 ustawy o ostateczności rozrachunku, siedem

41 Dz. U. z 2017 r. poz. 995.

42 Dz. U. z 2017 r. poz. 1060.

43 Raport o nadzorze systemowym w zakresie polskiego systemu płatniczego za $2018 \mathrm{r}$., grudzień 2019 r., s. 5, https://ssl.nbp.pl/systemplatniczy/nadzor/Raport-o-nadzorzesytemowym-2018.pdf [dostęp: 2.02.2020 r.]. 
decyzji w sprawie dokonania zmian w zasadach ich funkcjonowania. Natomiast na podstawie art. 132zm ustawy o usługach płatniczych wydał dwie decyzje $w$ sprawie prowadzenia schematu płatniczego oraz pięć decyzji w sprawie wprowadzenia zmian $w$ zasadach ich funkcjonowania ${ }^{44}$. Ponadto na wniosek KNF Prezes NBP, w ramach pełnionego nadzoru, wydał postanowienia zawierające dwie opinie w ramach nadzoru nad systemami rozliczeń i systemami rozrachunku papierów wartościowych ${ }^{45}$ oraz dwie opinie $\mathrm{w}$ ramach nadzoru nas świadczeniem usługi acquirin$g u^{46}$. Warto także odnotować, że w 2017 r. przedstawiciele NBP uczestniczyli w działaniach podejmowanych przez Europejski Bank Centralny oraz brali udział w pracach różnych komitetów i grup roboczych.

Mając na uwadze powyższe rozważania oraz analizę raportu o nadzorze systemowym w zakresie polskiego systemu płatniczego za 2018 r., należy stwierdzić z pełnym przekonaniem, że systemy płatności oraz systemy rozliczeń i rozrachunku papierów wartościowych w Polsce w 2018 r. funkcjonowały stabilnie, działania podejmowane przez operatorów systemów były właściwe, dążyły do sprawnego i bezpiecznego funkcjonowania systemu płatniczego. System płatniczy w 2018 r. funkcjonował prawidłowo, zapewniając sprawne i bezpieczne przeprowadzanie rozliczeń i rozrachunków ${ }^{47}$.

\section{Zakończenie}

Dokonując podsumowania badań przeprowadzonych na potrzeby niniejszego opracowania, warto odnotować, że zasady wykonywania przez NBP nadzoru systemowego w zakresie systemu płatniczego są rozproszone w kliku aktach prawnych, co utrudnia zbudowanie bezpiecznego i efektywnego funkcjonowania tego nadzoru. Krytycznej ocenie należy poddać zatem brak jednolitych podstaw prawnych wykonywania przez Prezesa NBP nadzoru systemowego. Trzeba podkreślić, że ustawa o usługach

${ }^{44}$ Tamże, s. 7-8.

45 Podstawa do wydawania takich opinii: art. 50 ust. 2 i art. 48 ust. 16 ustawy o obrocie instrumentami finansowymi.

46 Podstawa do wydawania takich opinii: art. 60 ust. 3 ustawy o usługach płatniczych.

47 Tamże. 
płatniczych odnosi się jedynie do nadzoru nad schematami płatniczymi. Wydaje się, że należałoby także dokonać przeglądu i weryfikacji zakresu nadzoru, o którym mowa w ustawie o ostateczności rozrachunku, w kontekście zakresu czynności podejmowanych przez NBP na gruncie ustawy o usługach płatniczych, w ramach nadzoru nad schematami płatniczymi. Pierwszy z nich jest stosunkowo wąsko zakreślony i obejmuje wydawanie zezwolenia, wprowadzanie zmian $\mathrm{w}$ zasadach funkcjonowania systemów płatności, ich kompleksową ocenę oraz wydawanie zaleceń. Z kolei zakres, o którym mowa w ustawie o usługach płatniczych, jest szerszy i zawiera obok wydawania zezwolenia, dokonywania oceny i wydawania zaleceń również czynności świadczące o uprawnieniach nadzorczych, tj. wydawanie decyzji o czasowym (częściowym lub całkowitym) wstrzymaniu funkcjonowania schematu płatniczego albo o cofnięciu zezwolenia na prowadzenie schematu, a także nakładanie kar pieniężnych. Mankamentem polskiego nadzoru systemowego jest oparcie go głównie na rozwiązaniach unijnych.

\section{Bibliografia}

Bajor B., w: Ustawa o ustugach ptatniczych. Komentarz, red. A. Zalcewicz, Warszawa 2016.

Górka J., Ryzyko w systemie płatniczym, Problemy Zarządzania 2013, t. 11, nr 2.

Jagielski J., Kontrola administracji publicznej, Warszawa 2012.

Koleśnik J., Obal T., Zaleska M., Budowa zintegrowanego systemu ochrony klientów instytucji finansowych w Polsce, Bezpieczny Bank 2007, nr 2-3.

Ochendowski E., Prawo administracyjne. Część ogólna, Torun 2013.

Sotomska-Krzysztofik P., Szczepańska O., Przejrzystość banków centralnych we wspieraniu stabilności finansowej, Bank i Kredyt 2006, nr 11-12.

Szczepańska O., Rola banku centralnego w sieci bezpieczeństwa finansowego, Bezpieczny Bank 2007, nr 2-3.

\section{Streszczenie}

Przedmiotem rozważań są rozwiązania prawne w odniesieniu do nadzoru systemowego w obszarze funkcjonującego w Polsce systemu płatniczego. Obowiązujące $\mathrm{w}$ powyższym zakresie przepisy, zarówno na poziomie krajowym, 
jak i unijnym, cechują się dużym rozproszeniem. Obejmują one kwestie ważne z punktu widzenia bezpieczeństwa i stabilności sektora finansowego. Celem dokonanej analizy jest pokazanie infrastruktury systemu płatniczego nadzorowanego przez Prezesa NBP oraz zwrócenie uwagi na zasady podejmowania przez bank centralny działań w omawianym zakresie. Szczególną uwagę zwrócono na Raport o nadzorze systemowym w zakresie polskiego systemu płatniczego za 2018 r., opublikowany przez NBP w grudniu 2019 r.

Przyjęta w opracowaniu metodologia badań została oparta na analizie kluczowych dla tytułowego zagadnienia tekstów aktów prawnych z odniesieniem do wybranych poglądów wyrażonych w literaturze przedmiotu. Posłużono się metodą prawno-porównawczą oraz dogmatyczno-prawną.

Omawiana problematyka dotyczy ważnego i stosunkowo nowego obszaru funkcjonowania banku centralnego, gdzie kluczowe cele wyznacza prawodawstwo unijne. Jednakże obszar funkcjonowania systemu płatniczego jest wyznaczony przez wewnętrzne przepisy kształtujące rynek finansowy. Zadania wypełniane $w$ tym zakresie przez NBP determinują nowy kierunek działalności banku centralnego. Ponadto na uwagę zasługuje współpraca pomiędzy NBP a KNF. Jest to niezwykle ważne z uwagi na odpowiedzialność za utrzymanie bezpieczeństwa finansowego.

Słowa kluczowe: bank centralny, nadzór, bezpieczeństwo finansowe, system płatniczy

\section{PRINCIPLES AND SCOPE OF SUPERVISION OVER PAYMENT SYSTEMS BY THE NATIONAL BANK OF POLAND}

\section{Summary}

The subject of the research described are legal solutions with regards to the systemic supervision in the scope of the payment system functioning in Poland. The provisions being applicable in the above scope, both on the national level, as well as in the EU, are marked by great dispersion. They include important issues from the point of view of safety and the stability of the financial sector. The aim of the analysis is to show the infrastructure of the payment system supervised by the Chairman the National Bank of Poland and pointing out the principles of taking actions by the central bank in the discussed scope. Particular emphasis was placed on the analysis "Report on the system supervision in the Polish payment system in 2018", published by the National Bank of Poland in December 2019.

The research methodology adopted in the study was based on the analysis of legal documents with taking into account various points of reference expressed in literature on the subject. The legal-comparative and dogmatic-legal research 
methods were used. The discussed issues regard an important and relatively new area of functioning of the central bank, where the EU legislation appoints the key goals. However, the area of operation of the payment system is determined by internal regulations shaping the financial market. The tasks performed by the NBP in this respect determine the new direction of activity of the central bank. In addition, the cooperation between the National Bank of Poland and KNF deserves particular attention. It is extremely important due to its responsibility for keeping financial security.

Key words: central bank, supervision, financial security, payment system

\section{ОБЪЕМ И ЗНАЧЕНИЕ ОСУЩЕСТВЛЕНИЯ НАЦИОНАЛЬНЫМ БАНКОМ ПОЛЬШИ СИСТЕМНОГО НАДЗОРА ЗА ПЛАТЕЖНЫМИ СИСТЕМАМИ}

\section{Резюме}

Предметом рассмотрения являются правовые решения в отношении системного надзора в области платежной системы, действующей в Польше. Нормативные акты, действующие в вышеупомянутой сфере, как на национальном уровне, так и на уровне ЕС, сильно различаются. Они охватывают вопросы важные для безопасности и стабильности финансового сектора. Цель проведенного анализа - показать инфраструктуру платежной системы, контролируемую председателем Национального банка Польши, и привлечь внимание к принципам действий центрального банка в этой области. Особое внимание было уделено Отчету о системном надзоре за платежной системой Польши за 2018 год, опубликованному Национальным банком Польши в декабре 2019 года.

Принятая в исследовании методология, была основана на анализе основных правовых актов, относящихся к исследуемому в настоящей статье вопросу, со ссылкой на избранные мнения, выраженные в научной литературе. Использовались сравнительно-правовой и догматико-юридический методы.

Обсуждаемый вопрос касается важной и относительно новой области деятельности центрального банка, ключевые цели которой определены законодательством ЕС. Однако сфера действия платежной системы определяется внутренними нормативными актами, формирующими финансовый рынок. Задачи, выполняемые Национальным банком Польши в этом отношении, определяют новое направление деятельности центрального банка. Кроме того, заслуживает внимания сотрудничество между Национальным 
банком Польши и Комиссией по финансовому надзору. Оно чрезвычайно важно с точки зрения ответственности за поддержание финансовой безопасности.

Ключевые слова: центральный банк, надзор, финансовая безопасность, платежная система 
